\title{
関係独自符号化による記憶増進と体制化構造 (4)
}

Kahana,M.J.の Lag 指標による分析の試み(2)

桐村 雅彦

(畿央大学 教育学部)

Key words: 多試行自由再生、体制化、記憶増進

【目的】桐村 (2006, 日心) と同様、すでに分析してきた体制化 構造の結果に、Kahana, M. J. が 1996 年以降に系列位置の親近

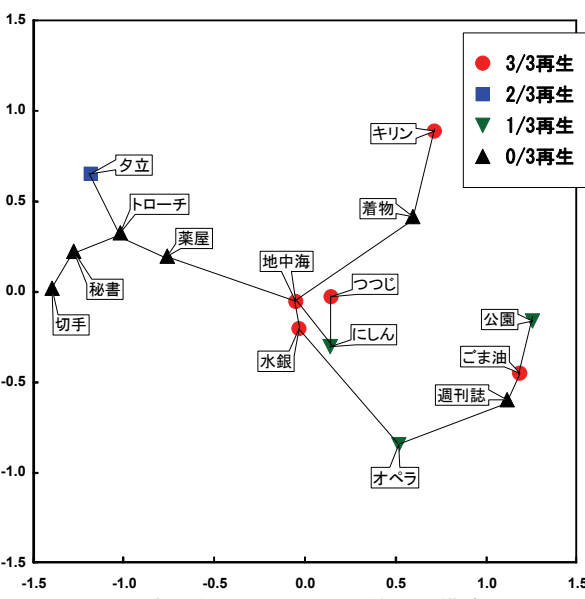

図1 後半自由再生3試行の体制化構造 (A1)

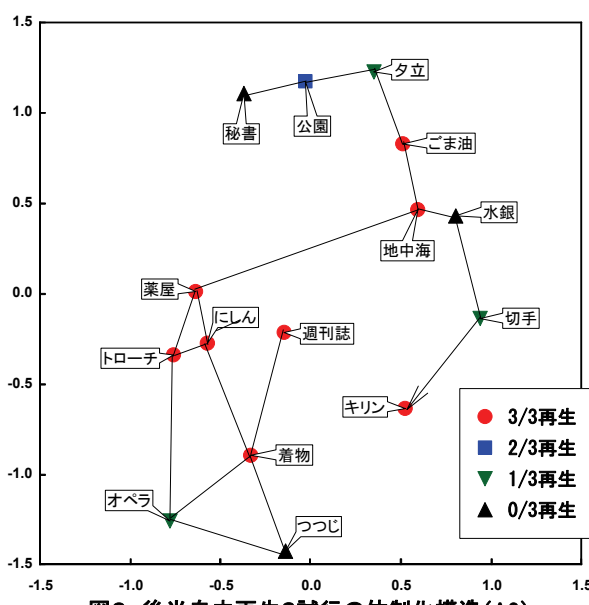

図2 後半自由再生3試行の体制化構造(A3)

性効果の分析に用

いている Lag 指標 を適用してみるこ とである。図 1 と 図 2 は桐村 (2004, 日心)での 2 名の 体制化構造図であ る。学習全項目の 自由再生結果から 図のような結果を 描くには、最低 2 試行の完全な全項 目再生順序が必要 で、この順序デー タから項目間の距 離行列を求め、多 次元尺度解析やパ スファインダーで 解析を行ない、散 布図に合成してい る。しかし一般に は自由再生試行で 全項目の完全再生 結果を得ることは 困難であり、特定 項目が全く再生さ れなかったり、中 途の再生試行で再 15 生失敗や再生成功 によって特定項目 が失われたり出現したりする(記憶増進の Gain と Loss)。項 目間の体制化構造の特徵ある内容と、記憶増進で観察される 再生時での消失・出現する特定項目とを、共に知る方策の検 討を行っている。【方法】《被験者》32 名の大学生を 2 リ ス卜に割り当て小集団実験を実施。《材料》 $\mathrm{A}$ リスト「地中 海, 薬屋, オペラ, つつじ, トローチ, キリン, 水銀, にしん, 秘書, ごま油, 夕立, 着物, 週刊誌, 公園, 切手」(Bリストは省略)の 15 語リストを使用。《手続き》 15 単語をランダム配置した A 5

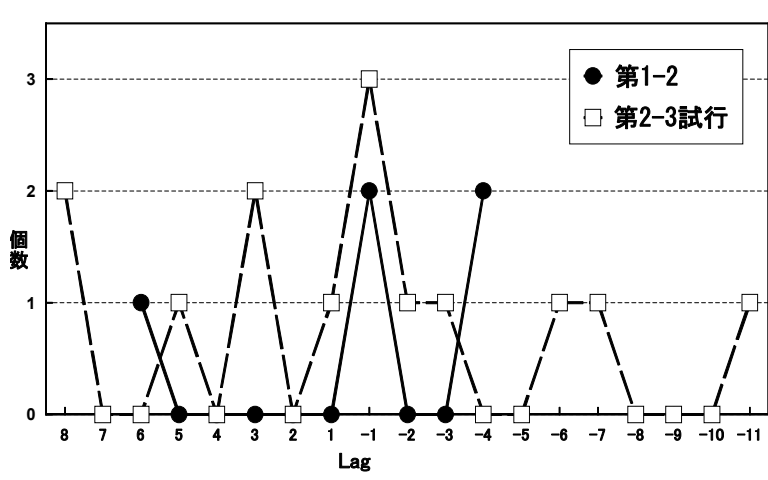

の冊

子を 配布 ᄂ、 符号 化の ため の想 起手 がか 図3 図1被験者の自由再生と手がかり再生間のLag値
題を行った[教示は「各ページの下段には後ほど想起してもら いたい記銘項目が印刷してあるので、その項目を後に想起す る際に役立つ手がかり連想語を上段枠内に記入し、さらにA4 別紙(手がかり一覽表)の所定枠に同じ手がかり語を記入」]。 この作業は 1 ページ 20 秒、全体で 5 分。検索は直後の自由再 生 3 試行。想起可能な多くの再生を求めた。再生時間は各試 行とも 1 分 30 秒。自由再生終了後、各自が作成した冊子を返 し、各ページ 5 秒で記銘項目の再学習と想起手がかりの確認 を求めた。再符号化課題は 1 分 15 秒。その後、3 試行の手が

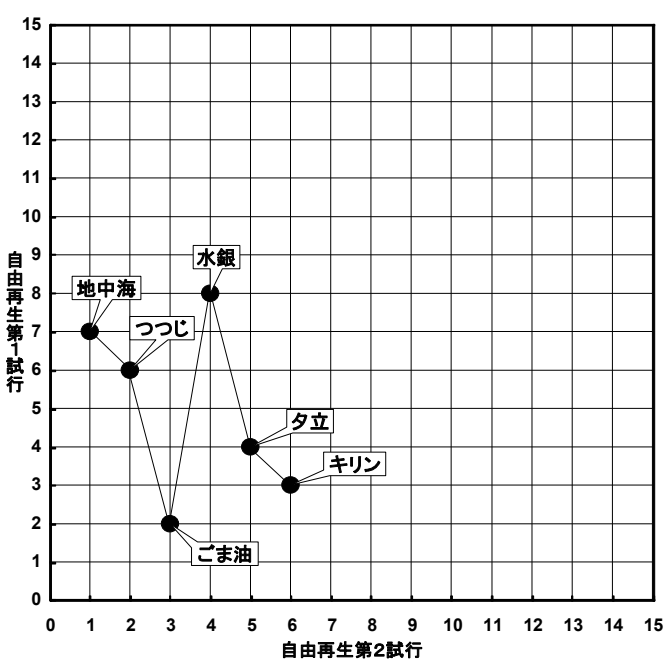

かり自由再生 を行った。各 試行の再生時 間は 1 分 30 秒。前半の自 由再生は記憶 増進、後半の 手がかり再生 は (主観的) 体 制化構造の課 題であった。

【結果】表 1 は自由再生 1 と 2 試行間と 手がかり再生 図4図1被験者の自由再生1と2試行間の関係

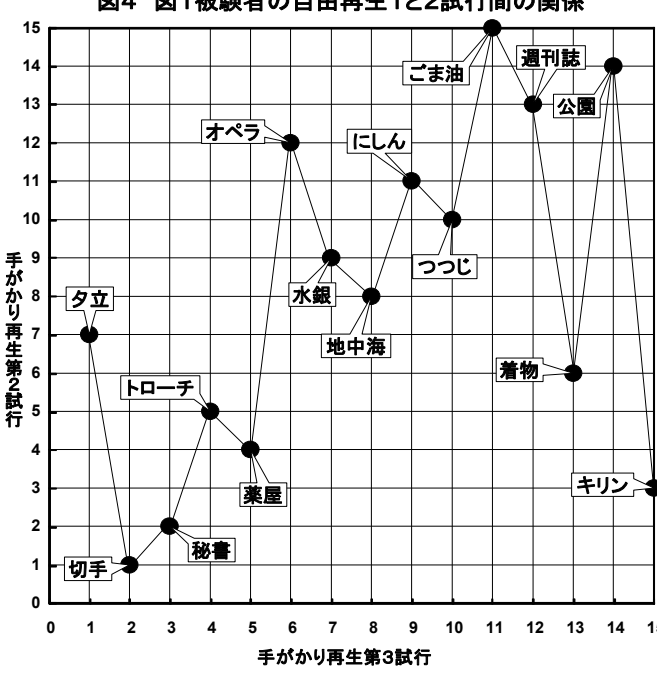
2 と 3 試行間 の Lag 值であ る。それらの 体制化構造を 多次元尺度解 析とパスファ インダーを合 成したのが図 4 と図 5 であ る。自由再生 2 試行では再 生項目数が少 なく、試行間 の反復が強固 ではない。し かし手がかり 再生 2 試行で は、15 全項目 が再生されていることに加え、試行間に安定した項目対の再 現が見られるようになっている。【考察】Lag の数值のみ による分析だけでは項目間の関係性まで充分に把握すること は不可能であり、かといって、試行間の再生順序によって項 目間の関係を散布図で描くだけでも不十分である。図 1 の体 制化構造が形成されていく継時的な構造的変化を描ききる工 夫は、目下のところ不十分であるといわざるを得ない。【引 用文献】代表的な文献としては、KLEIN，ADDIS，\& KAHANA A comparative analysis of serial and free recall, Memory \& Cognition, 2005, 33 (5), 833-839. (KIRIMURA Masahiko) 